Does the median voter consume too much water? Analyzing the redistributive r... Christopher Timmins

National Tax Journal; Dec 2002; 55, 4; ABI/INFORM Global

pg. 687

\title{
Does the Median Voter Consume Too Much Water? Analyzing the Redistributive Role of Residential Water Bills
}

\section{Christopher Timmins Department of Economics, Yale University, New Haven, CT 06520-8264}

National Tax Journal Vol. LV, No. 4

December 2002

\begin{abstract}
According to allocative efficiency criteria, water in the American West is often underpriced in urban sales. The politicaleconomic process that motivates municipal managers to impose the resulting deadweight losses on their constituencies is analyzed with a median voter model of choice between alternative municipal revenue sources. The implications of this model are tested empirically, and the results confirm the conclusions of previous empirical research by suggesting that cities with more skewed income distributions tend to engage in more redistributive activities than other conditionally similar communities.
\end{abstract}

\section{INTRODUCTION}

Some of the most important natural resource management $\mathcal{O}$ questions facing the United States today involve wateruse in the arid western states. Over the last 65 years, growing urban populations and the devotion of water resources to irrigated agriculture in this region, in conjunction with the more recent rededication of scarce supplies to environmental concerns (California DWR, 1994a), have resulted in substantial overuse of water relative to predicted long-run supply replenishment. Ultimately, this overuse is attributable to the failure of the price charged for water to accurately reflect, or even approach, its economic value. For example, massive government subsidies allow farmers to purchase water for irrigation from state and federal projects at a fraction of its opportunity cost. ${ }^{1}$ The costs of these subsidies are typically spread over large (i.e., statewide or national) constituencies that lack the political cohesiveness to correct the inefficiency. An inspection of the price paid for water by most municipal users in the West reveals similar subsidies. Unlike the broad tax base that pays for most agricultural transfers, however, these subsidies are funded by municipal taxpayers though either property taxes, sales taxes, user fees, a broad array of other taxes, or reductions in other municipal services. Within the smaller confines of a city, it is less likely that

${ }^{1}$ Examples include projects that "would return five cents in economic benefits for every taxpayer dollar invested," and another project that "offered irrigation farmers subsidies worth more than \$1 million each" (Reisner, 1986). 
this subsidy is attributable to failures of the political process; rather, it is the result of a public choice made by a group of rationally acting voters.

In other work (Timmins, 2002), the size of the allocational efficiency loss attributable to the subsidization of California municipal water users by municipal taxpayers has been quantified, accounting explicitly for the dynamic costs that arise when provision depends upon a renewable aquifer stock, as is often the case in the West. This loss is significant, averaging over 52 percent of the annual variable revenues collected from water provision for a representative city. That measure moreover, represents only a lower bound to the subsidy's social inefficiency costs, given its failure to include the external costs associated with the rapid depletion of groundwater (consider, for example, the costs related to land subsidence, groundwater quality degradation, desertification, and the reduced insurance against extended droughts).

In quantifying that lower bound on the inefficiency costs of municipalities' pricing decisions, municipal managers were assumed to act rationally in their choices to subsidize water use. In recognition of work in the political-economy literature that has studied the pricing decisions of municipally owned and operated firms, a reduced form of those decisions was specified as a tradeoff between the competing needs of water-consuming and tax-paying voters. This paper examines the optimizing behavior behind that reduced form, describing one possible set of motivations that would lead rationally acting municipal managers to impose deadweight losses of efficiency on their constituents, It explores the possibility that those managers, seeking continued employment through the electoral process, attempt to establish fiscal policies to please a majority of voters, but may be constrained in the tools they have available to do so. In particular, in an effort to make the municipality's overall revenue structure more progressive in response to an increasingly skewed income distribution, municipal managers may replace water bills with relatively progressive revenue sources. Income transfers might then be facilitated by running deficits in water production that are recouped with general tax revenues. A simple median voter model can be used to explain this idea. Such a model is illustrated, and its implications are tested with cross-sectional data describing 95 California municipalities in 1990.

This paper is organized as follows. Motivating the subsequent model, the second section briefly describes the incidence of charges for residential water use relative to that of substitute sources of municipal government revenue in California. The third section illustrates a stylized median voter model of water price and tax rate determination that rationalizes the water-underpricing decisions of politically savvy municipal managers, and the following section discusses a cross-section of data describing the water production, pricing, and use decisions of a representative group of California municipalities in 1990. These data allow the hypotheses arising from the stylized median voter model to be tested empirically in the fifth section. The paper concludes with a brief discussion of alternative explanations for water underpricing and policy options to reduce inefficiency in California municipal water use.

\section{THE INCIDENCE OF WATER CHARGES VERSUS GENERAL MUNICIPAL REVENUE SOURCES}

Goods and services provided by municipal utilities, like water, are commonly considered to be necessities. Formally, this means that their proportion of total household expenditures is represented by a decreasing function of income. This perception has been confirmed in numerous 
empirical studies. ${ }^{2}$ When a municipality earns revenues from charges levied on household water use, these studies find that the burden of those revenues falls disproportionately on the city's poorer residents. We would therefore expect water charges to constitute a regressive component of the municipality's general revenue structure, a fact that was recognized during California's latest drought, when water prices across the state were raised in order to reflect growing water scarcity. ${ }^{3}$ Municipalities wishing to redistribute income amongst their residents but with a limited set of fiscal tools at their disposal might therefore do so by substituting relatively progressive alternative revenue sources for those water charges-i.e., by charging lower prices for their water and making up the budget shortfall with different forms of tax revenue. Indeed, the empirical evidence presented later in this paper supports this hypothesis. The remainder of this section presents evidence that relatively progressive alternative revenue sources are in fact available to municipalities.

The regressivity of water charges is particularly evident when they are compared to the alternative revenue sources available to municipal managers; i.e., property taxes, sales taxes, and an assortment of other taxes, user fees, and miscellaneous charges. Figure 1 shows that, since the passage of Proposition 13 in 1978, the main source of discretionary (i.e., easily adjustable at the discretion of the local government) funds for California's cities has shifted from the property tax to these alternatives. While the property tax still contributes a substantial fraction of overall local revenues, municipal governments in the post-Proposition 13 era have virtually no control over the amount of funds it generates. Instead, local sales taxes have become increasingly important in California municipal revenue collection. ${ }^{4}$ To the extent that these taxes represent a general tax on all goods, they constitute a progressive source of municipal revenues relative to charges for only water, electricity, or gas. This is typically the rationale behind the exemptions given to these specific expenditures on necessities, like the goods and services provided by utilities, in state and municipal sales taxes. ${ }^{5}$

Table 1 provides some evidence on the relative incidence of the sales and

\footnotetext{
2 See, for example, Hewitt and Hanemann (1995); Martin and Wilder (1992); Cochran and Cotton (1985); Agthe and Billings (1980); and Howe and Linaweaver (1966); for studies of residential water demand, and Bernard, Bolduc and Belanger (1996); Branch (1993); Donatos and Mergos (1991); Westley (1989); Hsiao and Mountain (1985); Shin (1985); Barnes, Gillingham, and Hagemann (1981); Houthakker (1980); and Acton, Mitchell, and Mowill (1976); for studies of residential electricity demand.

3 "There is no doubt about it. Water shortages are regressive. Low-income people have a much more difficult time than the wealthy. If there is rationing, low-income people have more problems absorbing the increased water bills and fines," said Tim Quinn of the Metropolitan Water District of Southern California (Olazewski, 1991).

4 Several "sales and use" taxes are collected in California. The largest (currently 5.75 percent) is levied by the state, and contributes to both a statewide general revenue fund and a fund for specific local uses. A second component, the Bradley-Burns Tax, levies an additional uniform 1.25 percent on all sales, with 1 percent going to a general revenue fund in the city where the sale took place, and 0.25 percent going to that city's county government to support transportation projects. The Bradley-Burns Tax represents a discretionary source of municipal revenues only to the extent that cities can attract more retail businesses within their borders (Lewis and Barbour, 1999), but we make no attempt here to address the incidence of the policies designed to do so. The only truly discretionary component of the sales and use tax is an additional levy that can be imposed directly by the county or municipality. Currently, these optional taxes range between 0.125 and 1.25 percent. (California Legislative Analyst Office, 2001)

5 In the 1998-99 fiscal year, the California state government sacrificed $\$ 2,482,000,000$, while local governments gave up $\$ 782,000,000$, by giving sales tax exemptions to these commodities (along with exemptions for the purchase of steam and heat) (California Legislative Analyst Office, 2001).
} 

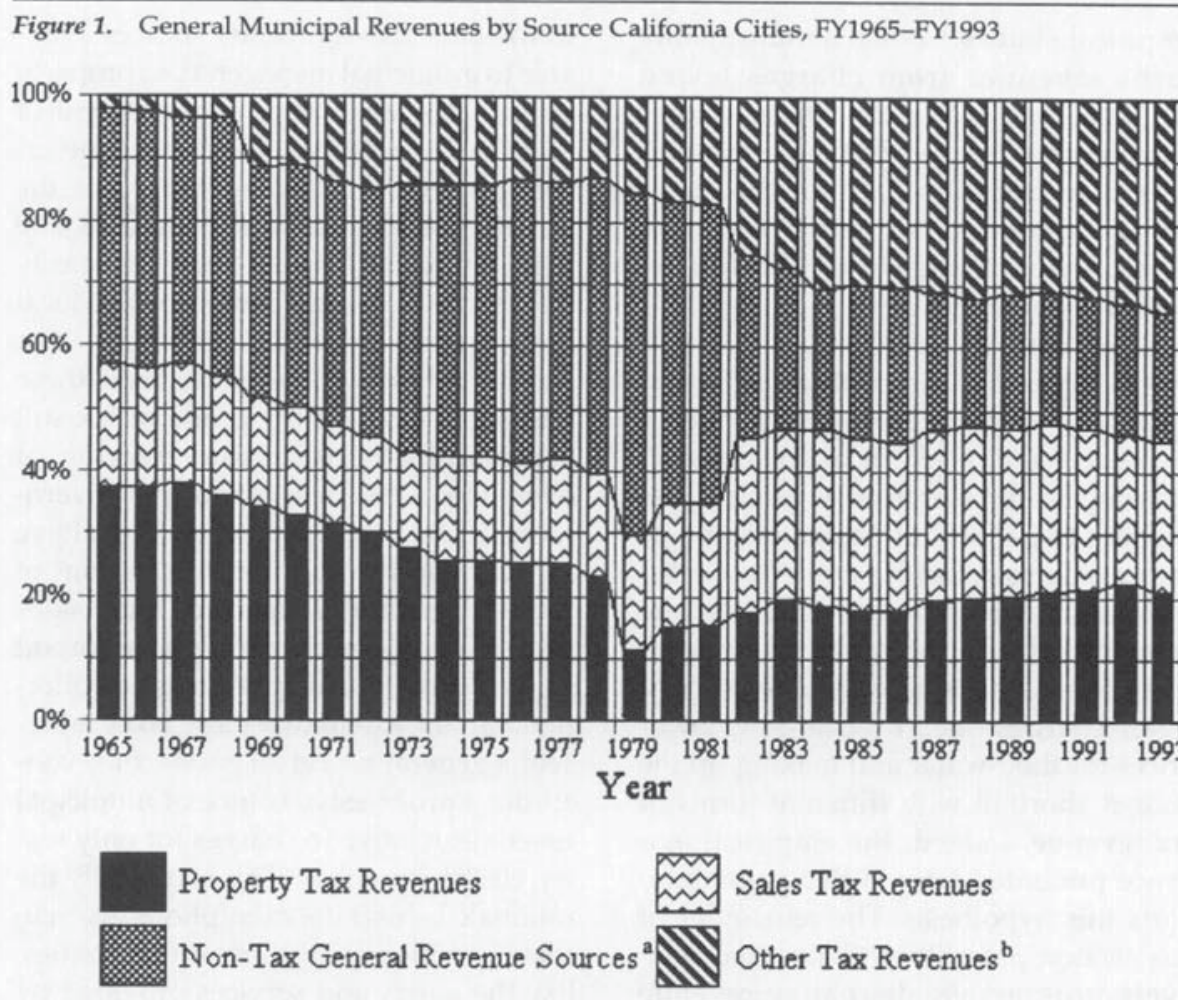

Source: Annual Report of Financial Transactions Concerning Cities of California. Fiscal Years 1965-66 to $1992-93$. California State Controller. General revenues do not include functional revenues, which are "revenues that can be associated with and allocated to one or more expenditure functions, and meet one of the following criteria: (1) The revenue is generated from direct services, such as revenues from fees or charges, (2) The revenue is associated with a specific service by external requirements, such as grant conditions, bond sale agreements, statutory or charter requirements."

${ }^{2}$ Non-Tax General Revenue Sources include (average component percentage over years in parentheses) (i) licenses and permits (4\%), (ii) fines and penalties (5\%), (iii) revenues from the use of money and property (19\%), (iv) revenues from other agencies $(59 \%)$, and (v) other revenues $(13 \%)$.

Other Tax Revenues include (average component percentage over years in parentheses) revenues from (i) transient lodging taxes (5\%), (iii) franchise taxes (10\%), (iv) business licence taxes ( $24 \%)$, (v) property transfer taxes $(2 \%)$, (vi) utility users taxes (44\%), and (vii) other non-property taxes $(15 \%)$.

property tax, ${ }^{6}$ along with the fees levied for water use in California in 1989. The columns describing the effective property and sales tax rates (i.e., total tax payments divided by household income) by income group are taken from Sheffrin and Dresch (1995) and report economic, as opposed to statutory, incidence (i.e., accounting for who truly bears the burden of the tax, not necessarily the entity who pays it di-

\footnotetext{
${ }^{6}$ While the property tax was not a discretionary source of revenue for California's cities after 1978, it is still worth considering in our analysis because it was those cities' primary source of discretionary revenue prior to the passage of Proposition 13. Timmins (2002) demonstrates that the cities' water price discounting behavior that we observe in 1990 was also present back into the early 1970s. To the extent that price discounts are observed in 1990 because they became politically entrenched more than 12 years prior, the relative incidence of the property tax is relevant to the current discussion. Keep in mind when interpreting the figures describing property tax incidence, however, that the post-Proposition 13 property tax (based on acquisition values) has been found to be slightly more progressive than the pre-Proposition 13 property tax system (based on market value assessment) (California Taxpayers Association, 1993).
} 
Does the Median Voter Consume Too Much Water?

TABLE 1

RELATIVE INCIDENCE OF RESIDENTIAL WATER CHARGES, PROPERTY AND SALES TAXES

\begin{tabular}{|c|c|c|c|c|c|c|}
\hline \multirow[b]{3}{*}{$\begin{array}{l}\text { Income } \\
\text { Group }\end{array}$} & \multirow[b]{3}{*}{ Income Range } & \multirow{2}{*}{\multicolumn{3}{|c|}{ Effective Tax Rate $=100 x$}} & Annual Expenditure & \multirow[b]{3}{*}{$\begin{array}{c}\text { Gas } \\
\text { Charge }\end{array}$} \\
\hline & & & & & Household Income & \\
\hline & & $\begin{array}{l}\text { Water } \\
\text { Charge }\end{array}$ & $\begin{array}{l}\text { Property } \\
\text { Charge }\end{array}$ & $\begin{array}{c}\text { Sales } \\
\text { Tax }\end{array}$ & $\begin{array}{c}\text { Electricity } \\
\text { Tax }\end{array}$ & \\
\hline 1 & $<5,000$ & 31.9 & 44.2 & 30.5 & 83.4 & 66.9 \\
\hline 2 & $5,000-10,000$ & 2.1 & 5.4 & 7.7 & 6.9 & 4.0 \\
\hline 3 & $10,000-20,000$ & 1.4 & 2.7 & 5.5 & 3.8 & 2.2 \\
\hline 4 & $20,000-30,000$ & 0.9 & 1.8 & 4.6 & 2.4 & 1.4 \\
\hline 5 & $30,000-40,000$ & 0.8 & 1.8 & 3.5 & 2.0 & 1.1 \\
\hline 6 & $40,000-55,000$ & 0.6 & 1.9 & 3.4 & 1.6 & 0.9 \\
\hline 7 & $55,000-70,000$ & 0.5 & 1.8 & 2.7 & 1.3 & 0.7 \\
\hline 8 & $70,000-100,000$ & 0.4 & 2.0 & 2.5 & 1.1 & 0.6 \\
\hline 9 & $>100,000$ & 0.3 & 2.2 & 2.5 & 0.8 & 0.5 \\
\hline \multicolumn{2}{|c|}{ Ratio: Group 1 to Group 9} & 106.3 & 20.1 & 12.2 & 104.3 & 133.8 \\
\hline \multicolumn{2}{|c|}{$\begin{array}{l}\text { Ratio: Average of Groups 1,2, } \\
\text { and } 3 \text { to the Average of } \\
\text { Groups } 8 \text { and } 9\end{array}$} & 33.7 & 8.3 & 5.8 & 33.0 & 44.3 \\
\hline \multicolumn{2}{|c|}{$\begin{array}{l}\text { Ratio: Average of Groups 2,3, } \\
\text { and } 4 \text { to Groups } 7 \text { and } 8\end{array}$} & 2.9 & 1.1 & 2.0 & 2.8 & 3.0 \\
\hline
\end{tabular}

Source: Property and sales tax incidence are calculated from data reported in Sheffrin and Dresch, 1995, while the incidence of charges for water, electricity, and gas are derived from a 0.1 percent random sample of California data maintained in the 1990 Census Public Use Microdata Files.

rectly). ${ }^{7}$ The effective rates for water use in Table 1 are calculated from a 0.1 percent random sample drawn from the California data maintained in the 1990 Census Public Use Microdata Files. For the sake of practicality and to achieve a sample that is more representative of the municipal households with which we are concerned, we ignore apartment and condominium dwellers when water charges are included as part of their rent or condominium fee, and households that do not receive water from either public or private water systems (i.e., households that get water from a spring or a well).

Results suggest that charges for water use constitute a regressive source of revenue relative to the property tax and, more importantly (from the point of view of discretionary funds), the sales tax. A simple measure of regressivity takes the ratio of the effective tax rate for some group at the bottom of the income distribution to that for a group at the top of the distribution. The bottom three rows of Table 1 illustrate three such measures. The first uses the extreme tails of the distribution (i.e., $<\$ 5,000$ relative to $>\$ 100,000$ ), while the second accounts for more of the middle of the income distribution (i.e., $<\$ 20,000$ relative to $>\$ 70,000$ ). A potential problem can arise in these sorts of analyses when using individuals in the " $<\$ 5,000$ " category, however, as some of them may actually be quite wealthy but have small or negative incomes in the year of analysis because of a shock to employment or a business loss. The final row of Table 1 therefore calculates the ratio of effective tax rates for individuals with incomes between $\$ 5,000$ and $\$ 30,000$ and individuals with incomes between $\$ 70,000$ and $\$ 100,000$. The results across all three measures of incidence are consistent for

\footnotetext{
7 The measure of sales tax incidence therefore accounts for both direct incidence (i.e., that accompanying retai) transactions) as well as indirect incidence (i.e., the price increases faced by consumers as businesses pass on a share of the taxes they pay on intermediate inputs). Similarly, the measure of property tax incidence accounts for both the direct burden on property owners as well as the indirect burden on renters.
} 
the water charge, property tax, and sales tax-the water charge is by far the most regressive revenue source.

Another significant source of discretionary revenue for localities in California comes from a collection of taxes, usually lumped together under the category "other". "These taxes are not often analyzed, and no comparable empirical evidence could be found from which to deduce their incidence. The bulk of local revenues in this category, however, come from the business license, franchise, and transient occupancy taxes; i.e., proportional taxes on gross receipts, lump-sum taxes on profits, and levies on non-residents, respectively. To the extent that these taxes are paid by members of the community at all, they are likely to be borne by the owners of capital, and to be progressive relative to charges for water.

Finally, utility user taxes ${ }^{9}$ have also become important sources of discretionary revenues in California municipalities since the passage of Proposition 13; indeed, revenues from this source comprise almost half of the "other" tax revenues described in Figure 1. The last two columns of Table 1 describe the incidence of charges for electricity and gas in California, derived from 1990 Census data in the same way as the effective tax rates for water use. While these effective tax rates do not account for indirect tax burdens passed on by businesses to consumers, they suggest that charges for electricity are nearly as regressive as charges for water use, while charges for gas are more regressive. The last result is potentially problematic for our analysis-if municipalities were using revenues generated from utility user taxes on gas to subsidize the price discounts given to water users, our income redistribution story would not be supported. Other reasonable explanations for the underpricing of water that are discussed in the conclusion, however, would not be supported either. Indeed, a story to explain such behavior on the part of municipal authorities would be quite complicated and beyond the scope of the present analysis.

A final explanation for municipal water price discounting behavior that deserves comment is that such discounts might not be funded with any of the discretionary tax sources described above, but rather with reductions in expenditures on other municipal services; for example, cities with larger water price discounts might pay for them by providing (substandard) police and fire protection at a lower cost. If the consumption of the affected municipal service were proportionally greater for those with higher incomes, the idea underlying our empirical analysis would be maintained, although the details of the model would be different. If consumption of the affected service were greater for those in the lower income brackets, however, the fundamental idea behind the model described in the next section would be undermined, suggesting some alternative explanation for water price discounts, such as "fiscal illusion," which we discuss in the conclusion. An analysis of the municipal budgeting process sufficient to discern which of these possibilities is true in practice is beyond the scope of the current exercise. This caveat, as well as that related to the use of discretionary taxes on gas consumers, should therefore be kept in mind when interpreting our results.

\footnotetext{
${ }_{8}$ This category includes the business license and transient occupancy taxes, which were responsible for $\$ 700$ and $\$ 900$ million in local revenues in the fiscal year 1997/98, along with franchise, documentary transfer, admissions, and parking taxes, and a host of other special taxes such as the Mello-Roos Community Facilities Tax, the library services tax, the parcel tax, and the police and fire services tax (California Legislative Analyst Office, 2001).

9 These are typically levies ranging from 0.5 to 12 percent that are imposed by the locality on the use of electricity, gas, cable television, water, and telephone services.
} 


\section{A MEDIAN VOTER MODEL OF WATER PRICE DETERMINATION}

A stylized model of choice between alternative municipal revenue sources by informed voters under a system of majority rule offers one plausible explanation of why municipal managers choose to subsidize the consumption of their water. The model described below is similar to that used by Meltzer and Richard (1981) to demonstrate how the "size" of government (measured by the amount of redistributive income transfers it undertakes) is determined by the distribution of income among voters. Whereas Meltzer and Richard focus on direct income transfers in a generalized model, the following model considers a special case-government transfers via taxpayer-subsidized water provision under specific functional forms. Functional form assumptions are made for analytic simplicity and empirical tractability; the conclusions of the model, however, are generalizable to a broad group of other functional forms.

The actors in this median voter model include heterogeneous water consuming households and a majority-elected municipal manager whose only role is to balance the municipal budget. The municipality's sole function is the provision of water, and it collects revenues from two sources: (i) water bills and (ii) income taxes, which are used in this simple model as a proxy for property taxes, sales taxes, and a collection of other taxes and user fees. ${ }^{10}$

Municipalities are assumed to consist of a continuum of households, indexed by $i$, that derive utility from the consumption of water, $w_{i}$, and a composite of all other goods, $x_{i}$. Utility is assumed to have a quasilinear form:
[1] $U\left(w_{i}, x_{i}\right)=b \ln w_{i}+x_{i}$.

Each household pays an income tax, which is assumed to be a constant proportion of income, $\tau I_{i}$. Household $i$ 's budget constraint is therefore given by:

$$
\text { [2] } P w_{i}+x_{i} \leq I_{i}(1-\tau) \text {, }
$$

where $P$ is the price of a unit of water, ${ }^{11}$ and the composite good acts as the numeraire commodity. Assuming that each household consumes all of its income, utility maximization yields demand for water that varies inversely with its price, and a corresponding demand for the numeraire commodity:

$$
\text { [3] } w_{i}=\frac{b}{P} \quad x_{i}=I_{i}(1-\tau)-b .
$$

The expenditure share of water represents a declining function of income (i.e., $b / I_{i}$ ), while tax payments as a proportion of income are constant (i.e., $\tau$ ). This reflects the differential incidence of water and tax bills described in the previous section. Households are assumed to differ in only their incomes, and income within a municipality is distributed according to $F(I)$.

The municipality is constrained to balance its budget each year. Its only costs are assumed to arise from providing water at a constant marginal cost, $c$. It receives revenues to offset these costs from water charges and from tax receipts:

$$
\begin{aligned}
& \text { [4] } P \int_{0}^{\infty} \frac{b}{P} f\left(I_{i}\right) d I_{i}+\tau \int_{0}^{\infty} I_{i} f\left(I_{i}\right) d I_{i} \\
& =\mathrm{c} \int_{0}^{\infty} \frac{b}{P} f\left(I_{i}\right) d I_{i} \text {. }
\end{aligned}
$$

Manipulation of this expression yields the municipality's "budget set," which

\footnotetext{
10 Since each of these revenue sources (with the exception of gas fees) was found in the second section to be progressive relative to water charges, it will suffice for modeling purposes to describe all of them with a single, relatively progressive, income tax. The use of an income tax (as opposed to a sales or property tax) simplifies the model by allowing progressivity to be represented without requiring additional behavioral assumptions regarding consumption patterns.

11 In the empirical analysis, $P$ will measure the price of an acre-foot of water. An acre-foot represents 325,851 gallons, or the quantity of water required to cover an acre at a depth of one foot.
} 
defines the relationship between its tax rate and its budget-balancing water price:

[5] $P=\frac{c b}{b+\tau E[I]}$.

Households are assumed to choose, by majority vote, a municipal manager whose only role is to determine a tax regime and the corresponding budgetbalancing price for water. Voters choose a politician based upon her platform's choice of marginal tax rate according to the following constrained utility maximization problem:

$$
\begin{gathered}
\max _{[\tau]} U=b \ln w_{i}+x_{i} \\
\text { [6] s.t. } \quad w_{i}=\frac{b}{P} \quad x_{i}=I_{i}(1-\tau)-b \\
P=\frac{c b}{b+\tau E[I]},
\end{gathered}
$$

which yields the following first-order condition:

[7] $\frac{b E[I]}{b+\tau E[I]}-I_{i}=0$.

With some manipulation, this condition determines the solution for household $i$ 's preferred tax rate:

[8] $\tau_{i}^{*}=\frac{b\left(E[I]-I_{i}\right)}{I_{i} E[I]}$.

Substitution of household $i$ 's choice of tax rate into the municipal budget constraint yields its corresponding preferred price of water:

[9] $P_{i}^{*}=\frac{c I_{i}}{E[I]}$.

Household $i$ therefore prefers to mark up or down the price of water to a percentage of marginal cost determined by its share of the mean income in the municipality.
Differentiating equation [7] with respect to $\tau$ in order to obtain $U^{\prime \prime}(\tau)$, we can see clearly that it is always negative and that household $i$ 's preferences over alternative tax rates are single-peaked.

$$
\text { [10] } U^{\prime \prime}(\tau)=-\frac{b(E[I])^{2}}{(b+\tau E[I])^{2}} \text {. }
$$

Moreover, according to equation [8], the optimal tax rates reflected by those peaks are ordered by income, with higher income households always preferring lower tax rates. Together, these features ensure an equilibrium in a majority voting system in which the preferences of the median voter will determine the outcome. In a typical right-skewed income distribution, the (pivotal) median voter will choose a price for water below marginal cost.

In order to derive an analytical result that can be easily taken to data, it is convenient to make a functional form assumption about the distribution of income within a municipality. Although most right-skewed income distributions would work, the log-normal distribution fits the income data well:

$$
\begin{aligned}
& \text { [11] } I_{i}=e^{x_{i}} \quad x_{i} \sim \text { i.i.d. } N\left(\mu, \sigma^{2}\right) \\
& \operatorname{Med}[I]=e^{\mu} \quad E[I]=e^{\mu+\frac{1}{2} \sigma^{2}} .
\end{aligned}
$$

The tax and water-price choices of the median voter are then determined:

$$
\text { [12] } P_{m}^{*}=\frac{c}{e^{\frac{1}{2} \sigma^{2}}} \quad \tau_{m}^{*}=\frac{b\left(e^{\frac{1}{2} \sigma^{2}}-1\right)}{e^{\mu+\frac{1}{2} \sigma^{2}}}
$$

Increasing $\sigma^{2}$ while holding $\mu$ constant increases the mean of the municipal income distribution relative to its median. Equation [12] illustrates that, with such a shift in the income distribution, the marginal price of water chosen by the decisive voter should decrease, conditional upon the marginal cost of provision. 
Cross-sectional variation in income distributions across cities will be used in the fifth section to test this hypothesis.

\section{DATA}

This paper employs a cross-sectional data set describing 95 California municipalities in 1990, their aggregate municipal water use, a variety of housing stock and household characteristics, and the pricing and factor-input decisions of their water utilities. These data can be divided into two categories: municipal characteristic data and economic decision data. Municipal characteristic data consist of the following. (1) Household income distribution (nine points) by municipality. (2) Measures of the housing stock, including the percentage of households that are condominiums, the percentage of households with zero or one bedrooms, the percentage of households with four or more bedrooms, the percentage of households that were built prior to 1939 , and the percentage of households built between 1980 and 1990. (3) Population and population density (average number of persons per household). Each of these series are observed in the 1990 Census and the City and County Data Book (1994).

Economic decision data describe the pricing and factor-input decisions made by municipal managers, the water-use decisions made by the aggregate of $\mathrm{mu}-$ nicipal residents, and the market equilibria that result from their interactions. They include the following. (1) Multi-part rate structures, describing fixed service charges, "free" water allocations accompanying payment of those service charges, and total revenues from residential water sales. (2) Expenditures on factor inputs, including water acquisition, treatment, pressurization and distribution, and administration. (3) The source of raw water inputs (i.e., ground versus surface water). (4) Aggregate municipal water consumption. These data are obtained from California State Controller Municipal Income and Expense Statements in combination with the California Department of Water Resources' Bulletin 166-4, "Urban Water Use In California" (California DWR, 1994b). The method by which the average marginal price for an acre-foot of water is derived from rate structure data is detailed in Timmins (2002). ${ }^{12}$ Marginal prices and marginal costs (assumed to equal average variable costs which are calculated from input expenditure and total output data) are combined to calculate each city's mark-up on water sales (i.e., (P-MC)/ $\mathrm{MC}$ ) in each year, which will serve as the dependent variable in the empirical analyses in the following section. Figure 2 illustrates the distribution of these markups, which are negative in 80 percent of the observations and which have a mean of -0.25 . Some cities exhibit very large mark-downs (e.g., as large as -0.88). It is the behavior of these cities, along with that of the many others that undertake less extreme price discounting, that our model seeks to rationalize.

Municipal characteristic and economic decision data are summarized by ownership-type in Tables 2 and 3. The final sample size of 95 cities represents the union of census, City and County Data Book, State Controller, and Department of Water Resources data sources. The proportion of publicly owned utilities in that sample (i.e., $68 / 95=72$ percent) is indicative of the proportion of publicly owned utilities in the state. This paper takes the

12 In short, marginal price figures are derived from two-part total revenue functions constructed from observed total revenue figures and data on fixed service charges, free water allocations, and total numbers of active service connections in each city. Under the assumption that the ratio of the fixed service charge to the free water allocation does not differ across connection types (e.g., commercial, industrial, governmental, and residential) within a city, the second leg of such a function describes the effective marginal price faced by a typical residential service connection. 
Figure 2. Mark-up Distribution In Municipal Water Supply (Full Sample)

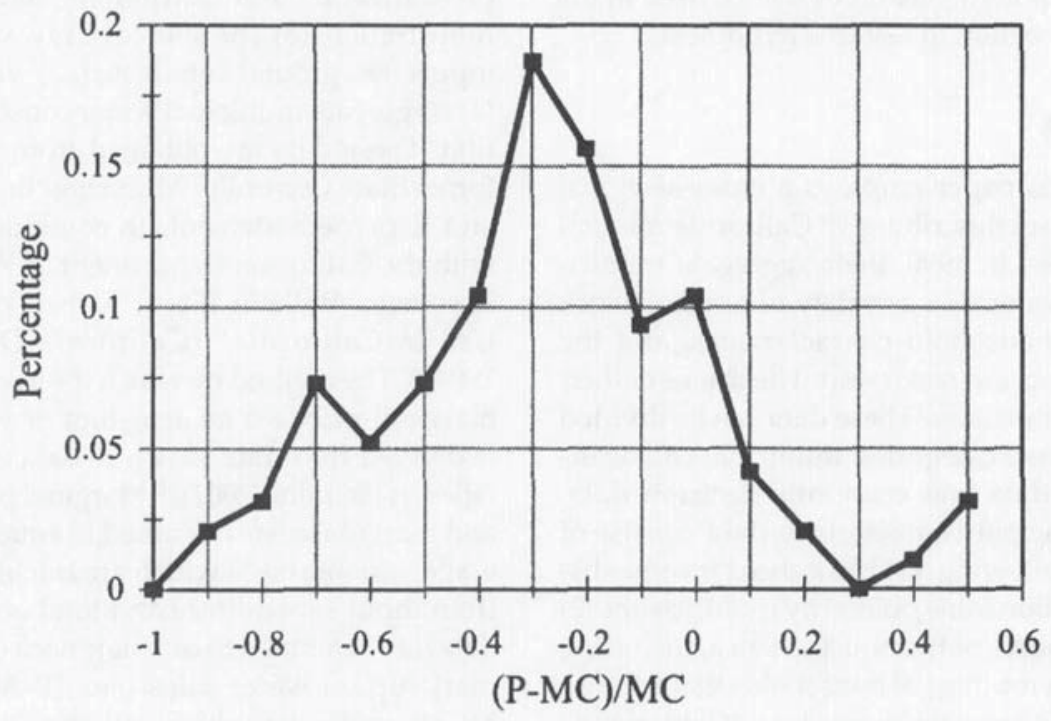

TABLE 2

CROSS-SECTIONAL DATA SUMMARY $\mathrm{N}=95$ (68 MUNICIPAL, 27 INVESTOR-OWNED)

\begin{tabular}{|c|c|c|c|c|c|}
\hline Variable & $\begin{array}{l}\text { Ownership } \\
=\text { municipal) }\end{array}$ & Mean & Std Deviation & Minimum & Maximum \\
\hline Marginal Price (\$/af) & $\begin{array}{l}0 \\
1\end{array}$ & $\begin{array}{l}265.03 \\
272.19\end{array}$ & $\begin{array}{l}131.12 \\
166.58\end{array}$ & $\begin{array}{l}16.61 \\
13.18\end{array}$ & $\begin{array}{l}672.43 \\
849.02\end{array}$ \\
\hline Average Variable Cost" & $\begin{array}{l}0 \\
1\end{array}$ & $\begin{array}{l}290.28 \\
371.94\end{array}$ & $\begin{array}{l}118.61 \\
200.36\end{array}$ & $\begin{array}{l}91.21 \\
38.61\end{array}$ & $\begin{array}{l}646.13 \\
949.67\end{array}$ \\
\hline Service Connections $(1,000 \mathrm{~s})$ & $\begin{array}{l}0 \\
1\end{array}$ & $\begin{array}{l}159.27 \\
129.69\end{array}$ & $\begin{array}{l}213.40 \\
418.08\end{array}$ & $\begin{array}{l}33.82 \\
25.42\end{array}$ & $\begin{array}{l}1118.28 \\
3433.56\end{array}$ \\
\hline Persons Per Household & $\begin{array}{l}0 \\
1\end{array}$ & $\begin{array}{l}582.00 \\
417.00\end{array}$ & $\begin{array}{l}258.00 \\
114.00\end{array}$ & $\begin{array}{l}314.00 \\
224.00\end{array}$ & $\begin{array}{r}1337.00 \\
866.00\end{array}$ \\
\hline$\%$ Houses: Built 1980-90 & $\begin{array}{l}0 \\
1\end{array}$ & $\begin{array}{l}21.00 \\
24.00\end{array}$ & $\begin{array}{l}11.00 \\
11.00\end{array}$ & $\begin{array}{l}5.00 \\
5.00\end{array}$ & $\begin{array}{l}48.00 \\
49.00\end{array}$ \\
\hline \% Houses: Built Pre-1939 & $\begin{array}{l}0 \\
1\end{array}$ & $\begin{array}{r}6.00 \\
10.00\end{array}$ & $\begin{array}{r}5.00 \\
10.00\end{array}$ & $\begin{array}{l}0.30 \\
0.10\end{array}$ & $\begin{array}{l}19.00 \\
55.00\end{array}$ \\
\hline$\%$ Houses: $0-1$ Bedrooms & $\begin{array}{l}0 \\
1\end{array}$ & $\begin{array}{l}23.00 \\
23.00\end{array}$ & $\begin{array}{r}11.00 \\
9.00\end{array}$ & $\begin{array}{l}9.00 \\
7.00\end{array}$ & $\begin{array}{l}49.00 \\
60.00\end{array}$ \\
\hline$\%$ Houses: $4<$ Bedrooms & $\begin{array}{l}0 \\
1\end{array}$ & $\begin{array}{l}14.00 \\
14.00\end{array}$ & $\begin{array}{l}9.00 \\
8.00\end{array}$ & $\begin{array}{l}2.00 \\
2.00\end{array}$ & $\begin{array}{l}38.00 \\
44.00\end{array}$ \\
\hline$\%$ Raw Water-Surface & $\begin{array}{l}0 \\
1 \\
\end{array}$ & $\begin{array}{l}47.00 \\
51.00\end{array}$ & $\begin{array}{l}37.00 \\
40.00\end{array}$ & $\begin{array}{l}0.00 \\
0.00\end{array}$ & $\begin{array}{l}100.00 \\
100.00 \\
\end{array}$ \\
\hline
\end{tabular}

a Measures all reported operating expenditures per acre-foot of water produced. 
Does the Median Voter Consume Too Much Water?

TABLE 3

INCOME DISTRIBUTION DATA

PERCENTAGE OF MUNICIPAL POPULATION BY INCOME CATEGORY AVERAGE ACROSS $\mathrm{N}=95$ CITIES

\begin{tabular}{lcccc}
\hline $\begin{array}{l}\text { Income } \\
\text { Range }\end{array}$ & $\begin{array}{c}\text { Mean } \\
\text { Percentage }\end{array}$ & $\begin{array}{c}\text { Standard } \\
\text { Deviation }\end{array}$ & $\begin{array}{l}\text { Minimum } \\
\text { Percentage }\end{array}$ & $\begin{array}{c}\text { Maximum } \\
\text { Percentage }\end{array}$ \\
\hline$<5,000$ & 003.7 & 001.6 & 001.3 & 008.7 \\
5,000 to 9,999 & 007.5 & 003.3 & 001.7 & 015.9 \\
10,000 to 14,999 & 007.4 & 002.8 & 001.8 & 015.2 \\
15,000 to 24,999 & 015.1 & 004.0 & 005.1 & 024.1 \\
25,000 to 34,999 & 015.0 & 002.2 & 008.8 & 019.2 \\
35,000 to 49,999 & 018.7 & 002.4 & 013.1 & 024.2 \\
50,000 to 74,999 & 019.1 & 005.3 & 007.8 & 031.8 \\
$>75,000$ & 013.5 & 007.8 & 001.9 & 038.6 \\
\hline
\end{tabular}

distribution of water utility ownershipform across California communities as given. While the determination of this ownership structure is interesting in itself (and could have statistical implications for the following analysis), a model of how each municipality originally chose its utility's ownership-form is beyond the scope of this study.

\section{WATER PRICE AND THE INCOME DISTRIBUTION}

The simple median voter model presented above suggests that the ratio of the price to the cost per unit of water should be inversely proportional to an increasing function of $\sigma^{2}$, the variance of the normal distribution underlying the lognormally distributed income. A greater variance in income should therefore lead to more extensive water-price subsidies at the expense of taxpayers. In order to test whether this is revealed in the data, marginal water price was measured for each city (indexed by $j$ ) in the cross-sectional data described in the previous section, and the difference between its natural logarithm and that of the average variable cost of water production was then regressed upon $\sigma_{i}^{2}$ and a vector of exogenous municipal and water utility system characteristics: $X_{j}=\{\#$ service connections, population density, housing stock variables, source of raw water input, hydrologic region indicator variables $\left.^{13}\right\}$. Each of these variables was intended to control for a factor that might influence the cost structure of municipal water production, altering the relationship described in equation [12] ${ }^{14}$ All variables except hydrologic region indicators in $X_{j}$ were expressed in logs, and $\sigma_{j}^{2}$ was recovered from the available data according to:

[13] $\sigma_{j}^{2}=2 *\left(\ln \left[\operatorname{Mean}(I)_{j}\right]-\ln \left[\operatorname{Median}(I)_{j}\right]\right)$,

where Median $(I)_{j}$ is observed in census data and Mean $(I)_{j}$ is approximated from the nine-point income distribution re-

\footnotetext{
${ }^{13}$ In particular, dummy variables were used to control for the municipality being in one of the following regions: San Francisco Bay, Central Coast, South Coast, Sacramento River, San Joaquin River, Tulare Lake, Colorado River. These variables should control for the many unobservable determinants of pricing behavior that are common to utilities facing similar conditions of water scarcity and supply, climate, and competition with other users (e.g., agriculture).

${ }^{14}$ For example, fixed service charges, which are assumed to cover the fixed costs of water provision, could be used as substitutes for property taxes in municipal revenue gathering. Cities with low fixed costs of water provision might be more able to use revenues from fixed charges to offset tax burdens, reducing the cost of the marginal tax dollar. This, in turn, would allow such cities to discount price below marginal cost more than a high fixed-cost city with a similar income distribution.
} 
ported in Bureau of the Census (1994). ${ }^{15}$ Our median voter theory suggests that this variable should be negatively correlated with the difference between log price and log cost. We initially consider only the 68 municipally owned and operated utilities in the cross-section, as the manager of an investor owned utility faces incentives that are different from those coming out of the median voter model. In particular, he is charged only with maximizing returns to shareholders, subject to regulatory constraints usually imposed by a state-level commission, and should not, therefore, account directly for the utility of local consumers, as would a municipal manager who relies upon those consumers' votes.

The first three columns of Table 4 report results of alternative specifications of this regression. In each, an increase in $\sigma_{j}^{2}$ is associated with a statistically significantly

TABLE 4

PRICE DISCOUNTING AND MUNICIPAL INCOME DISPERSION

DEPENDENT VARIABLE $=L N(P)-L N(c)$

HETEROSCEDASTIC-CONSISTENT STANDARD ERRORS

\begin{tabular}{|c|c|c|c|c|c|c|}
\hline & \multicolumn{3}{|c|}{$\begin{array}{l}\text { Municipally Owned Utilities } \\
\qquad(\mathrm{N}=68)\end{array}$} & \multicolumn{3}{|c|}{$\begin{array}{l}\text { Full Sample } \\
\qquad(\mathrm{N}=95)\end{array}$} \\
\hline & (1) & (2) & (3) & (4) & (5) & (6) \\
\hline Constant & $\begin{array}{l}-0.020 \\
(0.224)\end{array}$ & $\begin{array}{l}1.956 \\
(1.397)\end{array}$ & $\begin{array}{l}2.007 \\
(1.654)\end{array}$ & $\begin{array}{l}-0.079 \\
(0.161)\end{array}$ & $\begin{array}{l}2.174 \\
(0.974)\end{array}$ & $\begin{array}{l}1.945 \\
(1.029)\end{array}$ \\
\hline$\sigma^{2}$ & $\begin{array}{l}-1.251 \\
(0.674)\end{array}$ & $\begin{array}{l}-1.527 \\
(0.855)\end{array}$ & $\begin{array}{l}-1.807 \\
(0.919)\end{array}$ & $\begin{array}{r}-0.400 \\
(0.703)\end{array}$ & $\begin{array}{l}-0.688 \\
(0.882)\end{array}$ & $\begin{array}{l}-0.714 \\
(0.910)\end{array}$ \\
\hline $\begin{array}{l}\sigma^{2 *} \text { Municipal } \\
\text { Ownership }\end{array}$ & & & & $\begin{array}{r}-0.672 \\
(0.434)\end{array}$ & $\begin{array}{l}-0.883 \\
(0.440)\end{array}$ & $\begin{array}{l}-0.773 \\
(0.434)\end{array}$ \\
\hline $\begin{array}{l}\text { In Service } \\
\text { Connections }\end{array}$ & & $\begin{array}{l}-0.090 \\
(0.103)\end{array}$ & $\begin{array}{l}-0.067 \\
(0.116)\end{array}$ & & $\begin{array}{l}-0.094 \\
(0.083)\end{array}$ & $\begin{array}{r}-0.071 \\
(0.087)\end{array}$ \\
\hline $\begin{array}{l}\text { In Population } \\
\text { Density }\end{array}$ & & $\begin{array}{l}-0.054 \\
(0.392)\end{array}$ & $\begin{array}{r}-0.255 \\
(0.412)\end{array}$ & & $\begin{array}{l}-0.263 \\
(0.215)\end{array}$ & $\begin{array}{l}-0.357 \\
(0.203)\end{array}$ \\
\hline $\begin{array}{l}\text { In \% Houses: } \\
\text { Built 1980-90 }\end{array}$ & & $\begin{array}{l}0.036 \\
(0.145)\end{array}$ & $\begin{array}{l}0.021 \\
(0.167)\end{array}$ & & $\begin{array}{l}-0.010 \\
(0.096)\end{array}$ & $\begin{array}{l}0.029 \\
(0.109)\end{array}$ \\
\hline $\begin{array}{l}\text { In \% Houses: } \\
\text { Built Pre-1939 }\end{array}$ & & $\begin{array}{l}0.048 \\
(0.055)\end{array}$ & $\begin{array}{l}0.074 \\
(0.058)\end{array}$ & & $\begin{array}{l}-0.026 \\
(0.058)\end{array}$ & $\begin{array}{l}-0.000 \\
(0.057)\end{array}$ \\
\hline $\begin{array}{l}\text { In \% Houses: } \\
\text { Condominiums }\end{array}$ & & $\begin{array}{l}0.049 \\
(0.118)\end{array}$ & $\begin{array}{l}0.039 \\
(0.133)\end{array}$ & & $\begin{array}{l}0.016 \\
(0.094)\end{array}$ & $\begin{array}{l}-0.013 \\
(0.100)\end{array}$ \\
\hline $\begin{array}{l}\text { In \% Houses: } \\
\text { 0-1 Bedrooms }\end{array}$ & & $\begin{array}{l}0.617 \\
(0.331)\end{array}$ & $\begin{array}{l}0.491 \\
(0.401)\end{array}$ & & $\begin{array}{l}0.730 \\
(0.244)\end{array}$ & $\begin{array}{l}0.552 \\
(0.260)\end{array}$ \\
\hline $\begin{array}{l}\text { In \% Houses: } \\
4<\text { Bedrooms }\end{array}$ & & $\begin{array}{l}0.199 \\
(0.158)\end{array}$ & $\begin{array}{l}0.121 \\
(0.180)\end{array}$ & & $\begin{array}{l}0.164 \\
(0.122)\end{array}$ & $\begin{array}{l}0.088 \\
(0.136)\end{array}$ \\
\hline $\begin{array}{l}\text { In \% Raw Water: } \\
\text { Surface Water }\end{array}$ & & $\begin{array}{l}0.092 \\
(0.148)\end{array}$ & $\begin{array}{l}0.010 \\
(0.175)\end{array}$ & & $\begin{array}{l}0.064 \\
(0.126)\end{array}$ & $\begin{array}{l}-0.021 \\
(0.132)\end{array}$ \\
\hline $\begin{array}{l}\text { Hydrologic Region } \\
\text { Indicators }\end{array}$ & NO & NO & YES & $\mathrm{NO}$ & NO & YES \\
\hline $\mathrm{R}^{2}$ & 0.067 & 0.186 & 0.234 & 0.073 & 0.219 & 0.273 \\
\hline
\end{tabular}


greater discount of price below cost per unit, conditional upon system and municipality characteristics. The elasticity of the ratio $P / c$ with respect to changes in $\sigma_{i}^{2}$ varies between -1.25 and -1.81 , providing empirical support for the median voter model described above.

As a further test of this model, we can also check whether the same conditional correlation is present for the 27 investorowned utilities in the cross-section. The hypothesis is that investor-owned utilities, which do not strive to maximize the utility of a majority of their consumers as do municipally owned firms, will not exhibit the negative correlation found above. If it is present, the correlation may not be the outcome of the hypothesized median voter model, but rather the result of some other factor that is common to all California water utilities but ignored by the model. Columns 4,5, and 6 of Table 4 summarize the results of similar regressions performed on the full cross-section of 95 firms, allowing the coefficient on $\sigma_{j}^{2}$ to differ with ownership type $\left(O W N_{j}=1\right.$ in the case of municipal ownership, 0 if the utility is investor owned). ${ }^{16,17}$ The results of these regressions provide additional support for the median voter hypothesis. In each case, the conditional correlation between $\ln (P / C)$ and the log of the variance of the municipal income distribution is significantly more negative for the municipally owned utilities, and more than double the elasticity in each case. In ev- ery case, however, investor-owned utilities do exhibit smaller and statistically insignificant negative correlations, which could simply reflect the influence of the state regulatory agency in rate hearings.

Finally, it has been pointed out that municipal managers might offset reductions in the marginal price of water with increases in the fixed fees that are charged to households in exchange for being hooked-up to the distribution network. This would constitute an extremely regressive source of municipal revenues. The model implicitly assumes that fixed service charges are set so as to recoup the fixed costs of water provision, but in response to this possibility, note that all of the conclusions in Table 4 would still hold if average price-i.e., (fixed + variable revenues)/output-were used instead of marginal price. While this does not rule out the possibility that fixed fees could increase along with a reduction in marginal price, it does indicate that they cannot rise by very much.

\section{CONCLUSIONS}

The goal of this paper was to describe the motivations that lead the managers of municipally owned and operated water utilities to subsidize the use of their water at the expense of municipal taxpayers; the annual deadweight efficiency costs of such decisions have been measured in the millions of dollars. (Timmins, 2002) The

\footnotetext{
${ }_{16}$ A potential problem in this cross-ownership analysis arises from the possibility that ownership type and pricing behavior are both driven by some municipal attribute not observed in available data. While we cannot formally rule-out this possibility, it seems unlikely given the long period of time (i.e., decades) that have typically passed between the municipality's ownership-type decision and the pricing decisions we are considering

17 Additional specifications (not shown) included interactions between $O W N$ and the other municipal attributes in Table 4, including the regression constant. These additional interactions should play an important role in these regressions if other aspects of the firms' cost structures and pricing behavior (i.e., besides those associated with the variance of the municipal income distribution) differ with ownership status, which we would reasonably expect to be the case. Because of the small number of privately owned firms in the sample (27), however, estimates derived from these more general specifications were not statistically significant. In a limited alternative specification that included only a constant, $O W N, \sigma_{i}^{2}$, and $\sigma_{i}^{2}$ interacted with $O W N$, the interaction term had a coefficient of -0.93 with a $t$-statistic of -0.89 , providing weak evidence in support of the median voter hypothesis. Statistical significance further deteriorated as interactions between $O W N$, and ad ditional explanatory variables were included.
} 
results of the preceding empirical analyses support the hypothesis that the managers of municipally owned and operated water utilities, recognizing the needs of their water consuming constituents and out of a desire to win the approval of a majority of voters, discount price more in response to an increasingly skewed distribution of income. In particular, the elasticity of the ratio of price to cost per unit with respect to the variance of the normal distribution underlying the lognormally distributed household income ranges from -1.3 to -1.8 . These results provide empirical support for a special case of the same hypothesis put forth by Meltzer and Richard (1981) concerning the relationship between the "size" of government (i.e., its propensity to redistribute income) and the distribution of income in its constituency.

While the empirical results are consistent with this story of income redistribution, they clearly cannot rule-out every alternative explanation. Another possibility is that municipal residents simply react more strongly to water bills (i.e., charges for a well-defined commodity that arrive monthly in their mailboxes) than to tax bills (i.e., small increments they pay at every retail transaction or annual charges for a loosely defined set of public goods) at the ballot box. Political concerns would then dictate discounting water prices at the expense of higher tax bills. This type of fiscal illusion cannot be ruledout with the available data-rather, one can be almost certain that it does influence the way in which municipal managers price water, whether they also discount water sales for redistributive purposes or not. We can say, however, that there is no reason why we would expect to see this form of fiscal illusion appear more prominently in cities with less equal income distributions, so that, while it does contribute to our understanding of the decision to underprice water in general, it does not provide an explanation for the regression results in this paper. ${ }^{18}$

Having identified a likely motivation for municipal managers' pricing behavior, how might income redistribution be achieved while the costs of inefficient water overuse are reduced? Given the strict confines in which municipal finance is conducted, long-term Pareto welfare improvements might be achieved by subsidizing low-income consumers with price discounts (or sales tax rebates) applied to other publicly provided necessities (e.g., gas and electricity) that do not have the more immediate scarcity implications of water overuse. Alternatively, privatizing all municipal water provision would curtail management's incentive to subsidize water consumers by making its employment dependent upon only shareholder returns, but by itself, that solution would eliminate the equity-enhancing effects of the income redistribution that water subsidies currently facilitate. It is not clear that this would be socially desirable.

However the deadweight loss might be corrected, it is clear that achieving income redistribution by subsidizing consumption from a scarce water stock involves significant allocational inefficiency costs, as well as the potential for long-run supply exhaustion. Recognition of the motivations of municipal managers that are behind those subsidization decisions is the first step in dealing with California's growing water scarcity problems.

\section{Acknowledgments}

I would like to thank Frank Wolak, the participants in the Applied Microeconomics Workshops at Stanford and Yale Universities, several anonymous ref-

18 Given the extreme regressivity of water charges illustrated in the second section, we might expect to see politicians be more likely to exploit this form of fiscal illusion in cities with lower aterage incomes. Our regression results and the story about income redistribution, however, are premised on differences across cities in the variances of municipal income distributions. 
erees, and the editor for their insightful comments. All remaining errors and omissions are my own.

\section{REFERENCES}

Acton, J., B. Mitchell, and R. Mowill. Residential Demand for Electricity in Los Angeles, an Econometric Study of Disaggregated Data. Santa Monica, CA: Rand Corporation, 1976. Agthe, D.E., and R.B. Billings.

"Dynamic Models of Residential Water Demand." Water Resources Research 16 No. 3 (June, 1980): 476-80.

Barnes, R., R. Gillingham, and R. Hagemann. "The Short-Run Residential Demand for Electricity." Review of Economics and Statistics 63 No. 4 (November, 1981): 541-51.

Bernard, J., D. Bolduc, and D. Belanger. "Quebec Residential Electricity Demand: A Microeconometric Approach." Canadian Journal of Economics 29 No. 1 (February, 1996): 92-113.

Branch, R.E.

"Short Run Income Elasticity of Demand for Residential Electricity Using Consumer Expenditure Survey Data." The Energy Journal 14 No. 4 (1993): 111-21.

Bureau of the Census.

County and City Data Book. Washington, D.C.: U.S. Department of Commerce, 1994.

California Department of Water Resources. California Water Plan Update. Bulletin 160-93. State of California DWR, 1994a.

California Department of Water Resources. Urban Water Use In California. Bulletin 1664. State of California DWR, 1994b.

California Legislative Analyst Office. "California's Tax System: A Primer." Accessed 12/30/01. http://www.lao.ca.gov/ 2001/tax_primer/0101_taxprimer_ chapter1.html.

California Taxpayers Association.

"Proposition 13: Love it or Hate it, its Roots Go Deep." Cal-Tax Research Report, 1993.

Cochran, R., and A.W. Cotton.

"Municipal Water Demand Study, Oklahoma City and Tulsa, Oklahoma." Water Resources Research 21 No. 7 (July, 1985): 941-3.
Donatos, G., and G. Mergos.

"Residential Demand for Electricity: the Case of Greece." Energy Economics 13 No. 1 (January, 1991): 41-7.

Hewitt, J.A., and W.M. Hanemann.

"A Discrete/Continuous Choice Approach to Residential Water Demand Under Block Rate Pricing," Land Economics 71 No. 2 (May, 1995): 173-92.

Houthakker, $\mathrm{H}$.

"Residential Electricity Revisited." The Energy Journal 1 No. 1 (1980): 29-41.

Howe, C.W., and F.P. Linaweaver.

"The Impact of Price on Residential Water Demand and Its Relation to System Design and Price Structure." Water Resources Research 3 No. 1 (1967): 13-32.

Hsiao, C., and D. Mountain.

"Estimating the Short Run Income Elasticity of Demand for Electricity by Using Cross-sectional Categorized Data," Journal of American Statistical Association 80 No. 390 (June, 1985): 259-65.

Lewis, P., and E. Barbour. "California Cities and the Local Sales Tax." Public Policy Institute of California Report. San Francisco, CA: 1999.

Martin, R.C., and R.P. Wilder.

"Residential Demand for Water and the Pricing of Municipal Water Services." Public Finance. Quarterly 20 No. 1 (January, 1992): 93-102.

Meltzer, A.H., and S.F. Richard.

"A Rational Theory of the Size of Government." Journal of Political Economy 89 No. 5 (October, 1981): 914-27.

Olazewski, L.

"Water Shortage Hits Poor People Hardest." San Francisco Chronicle (April 16, 1991): A7.

Reisner, M.

Cadillac Desert: The American West and Its Disappearing Water. New York, NY: Viking Penguin Inc, 1986.

Sheffrin, S., and M. Dresch.

"Estimating the Tax Burden in California." Technical Assistance Program Report. California Policy Seminar, 1995.

Shin, J.

"Perception of Price When Price Information is Costly: Evidence from Residential Elec- 
tricity Demand." Review of Economics and Statistics 67 No. 4 (November, 1985): 591-8.

Timmins, $\mathrm{C}$.

"Measuring the Dynamic Efficiency Costs of Regulators' Preferences: Municipal Water Utilities in the Arid West." Econometrica 70 No. 2 (March, 2002): 603-29.
Westley, G.D.

"Nontraditional Partial Adjustment Models and Their Use in Estimating the Residential Demand for Electricity in Costa Rica." Land Economics 65 No. 3 (August, 1989): 254 71. 